\title{
Effects of Solar Radiation on Fertility and the Flower Opening Time in Rice Under Heat Stress Conditions
}

\author{
Kazuhiro Kobayasi \\ Shimane University \\ Japan
}

\section{Introduction}

This chapter focuses upon the effects of solar radiation on the flower opening time and panicle temperature, both of which significantly affect heat-stress-induced sterility in rice, although solar radiation affects crop growth rates and production through photosynthesis, the fundamental physiological function of green plants. Three possible traits that may mitigate the damage caused by high temperature during the flowering period in rice have been proposed (Zhao et al., 2010). The first trait is the formation of a long dehiscence at the base of the anther, but this trait is under genetic control so that it is not affected by solar radiation. The second trait is early morning flower opening to avoid high temperatures during anthesis. The flower opening time can be affected by solar radiation (Kobayasi et al., 2010). The third trait is panicle temperature, which can also be affected by solar radiation as well as microclimates and cultivar-related factors such as transpirational conductance and panicle shape (Yoshimoto et al., 2005). The latter two traits are discussed in this chapter.

Two experiments were conducted in Shimane Prefecture, Japan to reveal the roles of solar radiation in determining the flower opening time and panicle temperature. In section 2, the effects of solar radiation on the flower opening time have been examined. Early morning opening of rice flowers is a beneficial response to avoid heat-stress-induced sterility because the sensitivity of rice flowers to high temperatures decreases during the 1-hr period after flower opening (Satake \& Yoshida, 1978). The effects of solar radiation on the flower opening time were evaluated using generalized linear models. Cultivar differences in the contribution of solar radiation to the flower opening time were estimated. Furthermore, the roles of the diurnal change in solar radiation on determining the flower opening time were examined. In section 3 , the effects of solar radiation on panicle temperature have been examined. Atmospheric temperature is typically used to estimate temperature-dependent stress. However, solar radiation also affects plant tissue temperature. An empirical model to estimate the contribution of solar radiation to panicle temperature was developed using generalized linear models.

\section{Experiment 1: Effects of solar radiation on the flower opening time in rice}

Global climate change poses a serious challenge to crop production around the world. In rice (Oryza sativa L.), temperatures higher than $34{ }^{\circ} \mathrm{C}$ at the time of flowering may induce 
flower sterility and decrease yields, even in temperate regions such as southern Japan, if the cropping season is not changed to avoid such temperatures (Horie et al., 1996; Kim et al., 1996). Crop simulation models (Horie et al., 1996) have suggested that yields of currently grown rice varieties in southern Japan would be reduced by up to $40 \%$ under future climate scenarios. Serious yield losses in rice due to flower sterility occurred in the Yangtze Valley of China in 2003, when the temperatures during the hottest summer in the region's history affected the reproductive stage of rice cultivated in this region (Wang et al., 2004).

Early morning opening of rice flowers is a beneficial response to avoid sterility caused by heat stress during anthesis because the sensitivity of rice flowers to high temperatures decreases during the 1-hr period after flower opening (Satake \& Yoshida, 1978). Thus, a flower opening time, $1 \mathrm{hr}$ earlier than normal may reduce the risk of sterility because it may lead to anthesis before the air temperature reaches the critical level; air temperature can rise at a rate of higher than $3^{\circ} \mathrm{C} \mathrm{hr}^{-1}$ starting at approximately 1000 (Nishiyama \& Blanco, 1980). A controlled environment experiment revealed that flowers of 'Milyang 23' that opened earlier in the morning and at a lower temperature had higher seed sets than those that opened later (near midday) and at higher temperatures (Imaki et al., 1987).

Thus, the selection of cultivars with early flower opening times is an important method for reducing heat-induced sterility (Ishimaru et al., 2010; Jagadish et al., 2008; Nishiyama \& Blanco, 1980). For example, the flowers of O. glaberrima Steud. open earlier than those of $O$. sativa L. (Jagadish et al., 2008; Nishiyama \& Blanco, 1980), and the flowers of interspecific hybrids between $O$. glaberrima and $O$. sativa open earlier than those of $O$. sativa (Nishiyama \& Satake, 1981). Reduced sterility in the early morning flowering line subjected to rising temperatures during anthesis in the greenhouse was attributed to an earlier flowering time compared with 'Koshihikari' (Ishimaru et al., 2010).

Although the flower opening time is under genetic control, it is affected by aspects of the weather such as solar radiation and air temperature (Hoshikawa, 1989; Imaki et al., 1983; Jagadish et al., 2007, 2008; Kobayasi et al., 2010; Nakagawa \& Nagata, 2007; Nishiyama \& Satake, 1981). The relationship between the flower opening time and solar radiation has been researched under field conditions (Kobayasi et al., 2010). Using correlation analysis, most japonica cultivars showed a negative correlation between solar radiation and flower opening times; this correlation showed that higher solar radiation resulted in earlier flower opening times. However, the indica cultivar 'IR72' did not show a negative correlation between the solar radiation and flower opening time. This result suggests that the contribution of solar radiation to the flower opening time is different among ecotypes, and compared with japonica cultivars, indica cultivars have lower sensitivity in determining the flower opening time by solar radiation. Moreover, the response of flower opening to high temperature differs among rice cultivars. The flower opening time occurs earlier at high temperatures in 'Milyang 23', whereas it occurs later in 'Nipponbare' (Imaki et al., 1983). In a study of indica cultivars, the flower opening time occurred approximately $45 \mathrm{~min}$ earlier at higher temperatures (Jagadish et al., 2007). Furthermore, the relationship between solar radiation and air temperature should be incorporated into the analysis of the flower opening time because the amount of solar radiation is one of the most important factors in determining air temperature. It has been suggested that synergistic effects on the flower opening time may exist between temperature and light (Kobayasi et al., 2010). In addition to solar radiation and air temperature, other weather factors such as vapor-pressure deficit and wind speed (Tsuboi, 1961) affect the flower opening time. However, the combined effects of 
air temperature, solar radiation, vapor-pressure deficit, and wind speed on the flower opening time of various rice genotypes remain unclear, particularly under field conditions; this limits our ability to predict the flower opening time.

The cycle of solar radiation may also affect the flower opening time as well as the amount of solar radiation. Most studies on the effects of weather factors on the flower opening time have been conducted under controlled environments with artificial light conditions (Imaki et al., 1983; Jagadish et al., 2007, 2008; Nishiyama \& Blanco, 1981) and the flowers of rice plants grown in a glasshouse or a growth chamber have been reported to open 1-2 hr later than those grown outdoors (Imaki et al., 1982). This suggests that solar radiation substantially affects the flower opening time; not only the strength of solar radiation but also light conditions can influence the flower opening time because the duration of anthesis increases under continuous light or dark conditions (Hoshikawa, 1989). The light intensity and cycle of light and dark may affect the flower opening time. The effects of a diurnal cycle of light on the flower opening time in dicotyledonous Pharbitis nil flowers have been experimentally studied under artificially controlled conditions (Kaihara \& Takimoto, 1979).

In this section, first, the role of solar radiation in determining the flower opening time was evaluated using correlation analysis between solar radiation and the flower opening time. The correlations between the flower opening time and solar radiation averaged hourly, from 0500 to 1000 were analyzed. Second, we used general linear models to separately evaluate the effects of the type of cultivars, air temperature, solar radiation, vapor-pressure deficit, and wind speed on the flower opening time. In the second analysis, we used two types of 1hr time spans: a 1-hr time span based on Japan Standard Time, and a 1-hr time span based on the time of mean flower opening times in each cultivar; this eliminated the effects of the circadian rhythm. Finally, we attempted to detect the roles of the diurnal change in solar radiation in determining the flower opening time.

\subsection{Materials and methods}

Experiment 1 was conducted on an experimental field of Shimane University in Matsue, Shimane Prefecture, Japan $\left(35^{\circ} 29^{\prime} \mathrm{N}, 133^{\circ} 04^{\prime} \mathrm{E}, 4 \mathrm{~m}\right.$ above sea level) in 2010. Three indica cultivars and four japonica cultivars with wide ranges of flower opening times (Kobayasi et al., 2010) were used (Table 1). 'Xiaomazhan' had the earliest flower opening time in Japan (Kobayasi et al., 2010) and in Jiangsu Province, China (Zhao et al., 2010) among indica and japonica cultivars. Among japonica cultivars, 'Milky Queen' had the earliest flower opening time in Japan (Kobayasi et al., 2010) and in Jiangsu Province, China (Zhao et al., 2010). Although indica cultivars are not commonly planted in Japan, we used 'IR72' and 'Takanari' because the flowers of indica cultivars open earlier than those of japonica cultivars (Imaki et al., 1987).

The soil type at the study site was alluvial sandy clay. On three occasions, 30-day-old seedlings grown in nursery boxes were manually transplanted to the experimental field of Shimane University to obtain flowering plants under different weather conditions. Table 1 shows the seeding dates, ecotype, origin, and measurement periods for the flower opening time and weather factors. The planting density was 22.2 hills $\mathrm{m}^{-2}$ (one seedling per hill, 15$\mathrm{cm}$ hill spacing, and 30-cm row spacing). The area of each plot was $12.8 \mathrm{~m}^{2}$. A basal dressing of $4.0 \mathrm{~g} \mathrm{~m}^{-2}$ of $\mathrm{N}, 4.9 \mathrm{~g} \mathrm{~m}^{-2}$ of $\mathrm{P}_{2} \mathrm{O}_{5}$, and $4.3 \mathrm{~g} \mathrm{~m}^{-2}$ of $\mathrm{K}_{2} \mathrm{O}$ was applied. Top dressing was not used. Culture methods such as irrigation and pesticide used followed the standard local practices for rice production in Shimane Prefecture. 


\begin{tabular}{lllll}
\hline Cultivar & Ecotype & Origin & Seeding dates & Measurement period \\
\hline 'Fujihikari' & japonica & Japan & $\begin{array}{l}\text { April 15, } \\
\text { May 7 }\end{array}$ & July 13-20, 23-27 \\
'Koshihikari' & japonica & Japan & $\begin{array}{l}\text { April 15, } \\
\text { May 7, 28 }\end{array}$ & $\begin{array}{l}\text { July 26-31, } \\
\text { August 5-11, 17-21 }\end{array}$ \\
'Xiaomazhan' & indica & China & $\begin{array}{l}\text { April 15, } \\
\text { May 7, 28 }\end{array}$ & $\begin{array}{l}\text { July 25-29, } \\
\text { August 3-7, 20-25 }\end{array}$ \\
'Milky Queen' japonica & Japan & May 7, 28 & August 5-11, 17-21 \\
'IR72' & indica & Philippines & May 7, 28 & $\begin{array}{l}\text { August 24-29, } \\
\text { September 5-11 }\end{array}$ \\
'Takanari' & indica & Japan & May 28 & $\begin{array}{l}\text { August 28- } \\
\text { September 2 }\end{array}$ \\
'Asahi' & japonica & Japan & May 7, 28 & September 2-9 \\
\hline
\end{tabular}

Table 1. Ecotype, origin, seeding dates and measurement periods for the seven O. sativa cultivars used in Experiment 1.

\subsubsection{Measurements of the flower opening time and weather factors}

Physical stimuli such as touch may promote flower opening in rice (Tsuboi, 1961). To avoid this phenomenon, we used digital photographs of the panicles instead of physical inspections. The panicles were photographed at 10-min intervals with waterproof digital cameras (Optio W30, Pentax, Tokyo, Japan) to determine the flower opening time of the seven cultivars. The photographs were automatically taken using cameras. We put the camera on a tripod and used a built-in electronic timer to control the measurement intervals. We recorded the time of anther extrusion of all observable flowers (more than $30 \%$ of flowers in a panicle) on the obverse side of approximately 10 panicles per day per cultivar. The medians of anther extrusion time among all observed flowers in each panicle were calculated. The flower opening time was defined as the mean of the medians per day. Recording the anther extrusion time of the flowers behind panicles and leaves was occasionally difficult.

We measured air temperature, solar radiation, relative humidity, and wind speed every 5 min using a wireless weather station (Wireless Vantage Pro, Davis Instruments, Hayward, CA, USA), which was located at the experimental field of Shimane University (http://www.ipc.shimane-u.ac.jp/weather/station/i/home.html). The weather station was installed at a distance of approximately $5 \mathrm{~m}$ from observation plots. The ground surface below the station was covered with grass. We installed a thermometer, hygrometer, solarimeter, barometer, and an anemometer at heights of 150, 150, 180, 150, and $300 \mathrm{~cm}$, respectively. At our study site, the sun rose between 0502 (July 13) and 0547 (September 11); thus, we did not measure solar radiation before twilight. Vapor-pressure deficits were calculated from air temperature and relative humidity using the method based on microclimate (Buck, 1981). 


\subsubsection{Statistical analysis}

Pearson's correlation analysis was used to identify the relationship between solar radiation and the flower opening time. In this analysis, hourly average of solar radiation values between 0500 and 1000 were used. Correlation analysis was restricted to the period between 0500 and 1000 because sunrise hours during the flower opening time observation periods were around 0500, and flowers of 'Xiaomazhan' usually started to open before 1000. It is possible that the span in which flowers respond to solar radiation before flower opening are different among cultivars, i.e. cultivars with early morning flowering would respond earlier in the morning to solar radiation. Hourly average of solar radiation values were used over seven 1-hr periods based on the mean flower opening time in each cultivar (successive 1-hr periods from $7 \mathrm{hr}$ before the mean flower opening time until $1 \mathrm{hr}$ before the mean flower opening time).

The collected data were analyzed by means of generalized linear models and multiple regression procedures using SPSS (Version 14J for Windows, SPSS Japan Inc., Tokyo, Japan). Because inherent relationships exist among weather factors, relatively high correlations may exist among solar radiation, air temperature, vapor-pressure deficit, and wind speed. Therefore, to evaluate their individual effects as well as cultivar effects on the flower opening time, generalized linear models were used. In this analysis, solar radiation, air temperature, vapor-pressure deficit, and wind speed values were averaged over five 1-hr periods (0500-0600, 0600-0700, 0700-0800, 0800-0900, and 0900-1000). The relative contribution of each weather component to the flower opening time was determined using their standardized partial regression coefficients, and the overall strength of the relationships was quantified using the multiple correlation coefficients. The contribution of solar radiation, air temperature, vapor pressure deficit, and wind speed to the flower opening time in each cultivar was estimated by substituting the obtained weather data in the generalized linear models, and the relative contributions of solar radiation, air temperature, vapor pressure deficit, and wind speed to the flower opening time among the cultivars were evaluated. To examine the role of diurnal changes in solar radiation in determining the flower opening time, multiple correlation coefficients from 1800 on the day before flowering to 0900 on the flowering day were calculated for each cultivar.

\subsection{Results}

In 2010, record heat and sunshine occurred in Japan because a strong North Pacific High covered the country during summer. The total solar radiation between 0000 and 1200 during the flower opening time observation periods ranged from 1.0 to $13.3 \mathrm{MJ} \mathrm{m}^{-2}$. Sunshine hours in the former and latter halves of August 2010 were 6.58 and 9.75, respectively. The normal sunshine hour in August is 6.47. This suggests that average solar radiation during the flower opening time observation periods was higher than usual in that year. The vapor-pressure deficit between 0000 and 1200 during the flower opening time observation period ranged from 1.9 to $18.3 \mathrm{hPa}$.

The maximum and minimum air temperature between 0000 and 1200 during the flower opening time observation period ranged from 24.6 to $36.7^{\circ} \mathrm{C}$ and from 19.4 to $27.3^{\circ} \mathrm{C}$, respectively (Fig. 2). In particular, the mean air temperatures between the latter part of July and August in 2010 reached record-high levels. The maximum and minimum air temperature increased rapidly from mid-July through early August. The maximum air temperature was higher than $34^{\circ} \mathrm{C}$ (temperatures $>34^{\circ} \mathrm{C}$ at the time of flowering may induce flower sterility and decrease yield) for 23 days, however, in normal years, the maximum air temperature was rarely higher than $34^{\circ} \mathrm{C}$. 


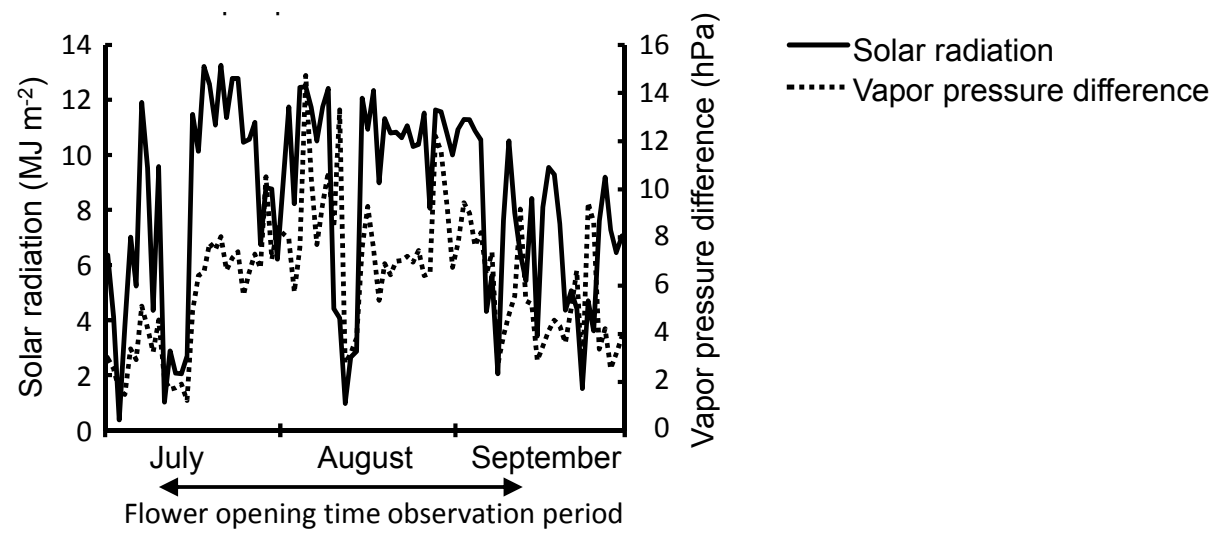

Fig. 1. Total solar radiation and average vapor-pressure deficit between 0000 and 1200 during the observation period.

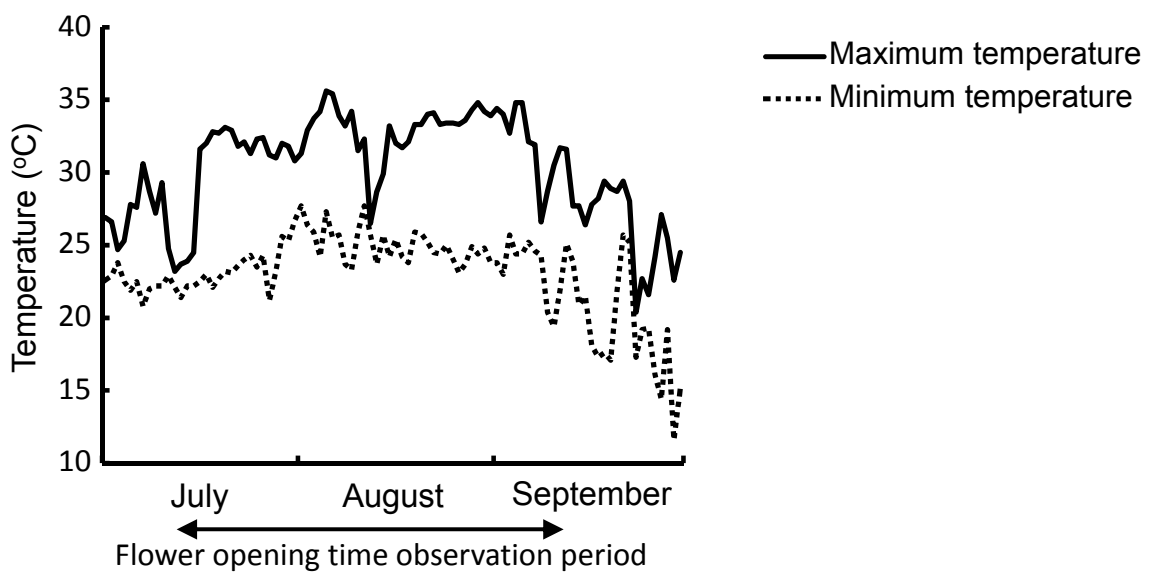

Fig. 2. Maximum and minimum temperatures between 0000 and 1200 during the observation period.

Average wind speed and atmospheric pressure ranged from 0.0 to $1.4 \mathrm{~m} \mathrm{~s}^{-1}$ and from 1001 to $1017 \mathrm{hPa}$, respectively, between 0000 and 1200 during the flower opening time observation period. The wind speed and atmospheric pressure were stable because a strong North Pacific High covered Japan during the summer of 2010.

Significant correlations existed between the meteorological variables. In particular, the correlation between air temperature and vapor-pressure deficit was high $(\mathrm{r}=0.715, p<$ $0.001)$. The correlation between solar radiation and air temperature and that between solar radiation and vapor-pressure deficit were also relatively high $(\mathrm{r}=0.532, p<0.001 ; \mathrm{r}=0.664$, $p<0.001$, respectively). Wind speed and atmospheric pressure had relatively weak correlations $(r<0.5)$ with other meteorological variables. 


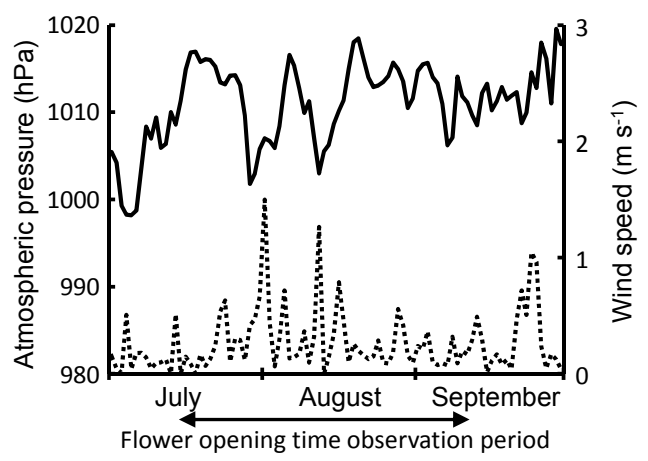

\section{-Atmospheric pressure Wind speed}

Fig. 3. Average vapor-pressure deficit and average wind speed between 0000 and 1200 during the observation period.

\subsubsection{Variations in the flower opening time during the observation periods}

Although flower opening time is under genetic control, wide ranges in flower opening time were recorded in all seven cultivars. Cultivar 'Xiaomazhan' flower opening time recorded 1-2 hr earlier than other cultivars. The flowers of the indica cultivars ('Xiaomazhan', 'IR72', and 'Takanari') opened earlier than those of the japonica cultivars ('Fujihikari', 'Koshihikari', 'Milky Queen' and 'Asahi'). The flowers of 'Milky Queen' did not open earlier than those of the other japonica cultivars although its flowers opened early in Japan (Kobayasi et al., 2010) and China (Zhao et al., 2010). The range in the flower opening time was higher than $2 \mathrm{hr}$ in 'Fujihikari', 'Xiaomazhan', and 'IR72'.

\subsubsection{Correlations between solar radiation and the flower opening time}

The six cultivars other than 'Takanari' showed negative correlations between the flower opening time and mean hourly solar radiation for every hour between 0500 and 1000 (Fig. 4). The cultivars can be classified into two groups. One group showed negative, high correlations and comprised the indica cultivar 'IR72' and japonica cultivars 'Fujihikari', 'Asahi', and 'Milky Queen'. The other group showed relatively weak correlations and comprised the indica cultivars 'Takanari' and 'Xiaomazhan' and the japonica cultivar 'Koshihikari'.

\begin{tabular}{lccc}
\hline \multicolumn{1}{c}{ Cultivar } & $\begin{array}{c}\text { Flower } \\
\text { opening time }\end{array}$ & $\begin{array}{c}\text { Mean flower } \\
\text { opening time }\end{array}$ & $\begin{array}{c}\text { Range in the flower } \\
\text { opening time }\end{array}$ \\
\hline 'Fujihikari' & $0958-1250$ & 1124 & 172 \\
'Koshihikari' & $1049-1244$ & 1136 & 115 \\
'Xiaomazhan' & $0726-0944$ & 0858 & 138 \\
'Milky Queen' & $1053-1226$ & 1132 & 93 \\
'IR72' & $0946-1152$ & 1030 & 126 \\
'Takanari' & $1011-1109$ & 1038 & 58 \\
'Asahi' & $1053-1205$ & 1122 & 72 \\
\hline
\end{tabular}

Table 2. Variations in the flower opening time, mean flower opening time, and range in flower opening time expressed as Japan Standard Time for seven O. sativa cultivars in 2010. 


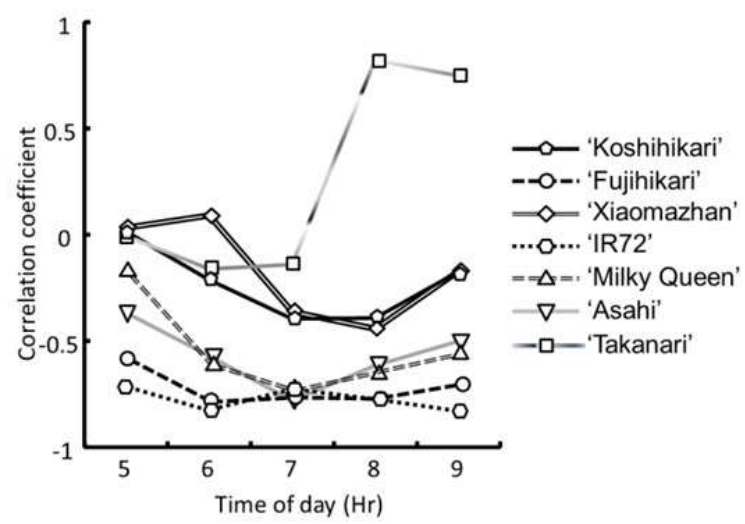

Fig. 4. Correlation coefficients between the flower opening time and hourly solar radiation for each hour from 0500 to 1000 in seven O. sativa cultivars.

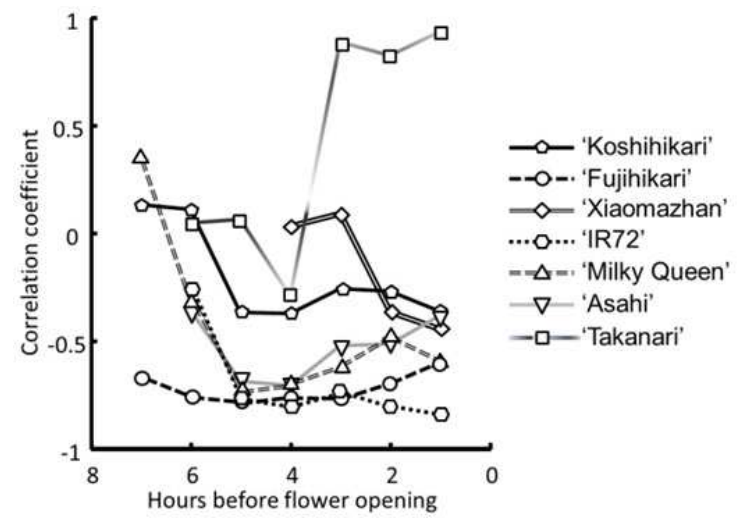

Fig. 5. Correlation coefficients between the flower opening time and hourly solar radiation for each hour over seven 1-hr periods based on the mean flower opening time in each cultivar (successive 1-hr periods from $7 \mathrm{hr}$ before mean flower opening time until $1 \mathrm{hr}$ before flower opening time)

To examine the difference in response hours to solar radiation before flower opening among cultivars, correlation coefficients between the flower opening time and hourly solar radiation were calculated for each hour over seven 1-hr periods based on the mean flower opening time in each cultivar (successive 1-hr periods from $7 \mathrm{hr}$ before mean flower opening time until $1 \mathrm{hr}$ before flower opening time; Fig. 5). The correlation coefficients of the cultivars classified as the group that showed negative, high correlations (Fig. 4) dropped rapidly at five hours before flower opening. At five and four hours before flower opening, the correlation coefficients of the group with negative, high correlations remained at approximately -0.7 . Although the obtained negative correlation was weak, the correlation coefficients of 'Takanari' and 'Koshihikari' dropped at $5 \mathrm{hr}$ before flower opening. We did not calculate the correlation coefficients between flower opening time and solar radiation in 'Xiaomazhan' because the flowers of this cultivar opened before 1000 . 


\subsubsection{Evaluation of the effects of solar radiation, on cultivar's, air temperature, vapor- pressure deficit, and wind speed on the flower opening time}

The multiple correlation coefficients determined by generalized linear model increased after 0400 and peaked between 0700 and 0800 (Fig.6) and then slightly decreased after 0800 . The highest multiple correlation coefficient (adjusted $\mathrm{R}^{2}=0.849, p<0.001$ ) was obtained for the 0800-0900 period (Table 3). During this period, three factors (cultivar type, solar radiation, and air temperature) were significant $(p<0.05)$. The standardized partial regression coefficient for air temperature was -0.131 , indicating that higher air temperature during this period resulted in an earlier flower opening time. Similarly, the standardized partial regression coefficient of solar radiation was -0.002 , indicating that higher solar radiation during this period also resulted in an earlier flower opening time. The standardized partial regression coefficients for the other two weather factors (vapor-pressure deficit and wind speed) were not significant except for wind speed during the $0500-0600$ period. The estimated contributions (hr) of each cultivar were $-2.16,-0.89,-0.37,-0.01,0,0.41$, and 0.437 for 'Xiaomazhan', 'IR72', 'Takanari', 'Fujihikari', 'Asahi', 'Koshihikari', and 'Milky Queen' respectively.

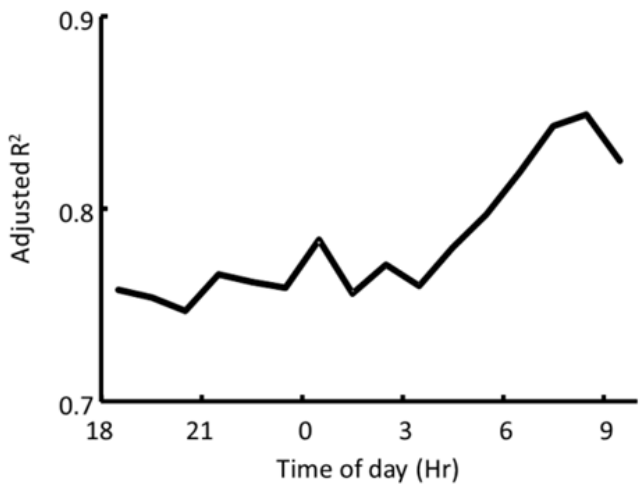

Fig. 6. The multiple correlation coefficients (adjusted $\mathrm{R}^{2}$ ) obtained from multiple regression analysis using general linear models. The correlations for four weather factors (air temperature, solar radiation, vapor-pressure deficit, and wind speed) and the flower opening time for the 1-hr periods based on Japan Standard Time were analyzed.

\begin{tabular}{ccccccc}
\hline & \multirow{2}{*}{$\begin{array}{c}\text { Multiple- } \\
\text { Period }\end{array}$} & \multicolumn{4}{c}{ F values in generalized linear models } \\
\cline { 3 - 7 } & $\begin{array}{c}\text { correlation } \\
\text { coefficient }\end{array}$ & Cultivar & $\begin{array}{c}\text { Air } \\
\text { temperature }\end{array}$ & $\begin{array}{c}\text { Solar } \\
\text { radiation }\end{array}$ & $\begin{array}{c}\text { Vapor- } \\
\text { pressure } \\
\text { deficit }\end{array}$ & $\begin{array}{c}\text { Wind } \\
\text { speed }\end{array}$ \\
\hline $0500-0600$ & $0.797^{* * *}$ & $12.44^{* * *}$ & $1.22^{*}$ & $1.43^{*}$ & $0.36 \mathrm{~ns}$ & $1.88^{* *}$ \\
$0600-0700$ & $0.819^{* * *}$ & $12.77^{* * *}$ & $1.40^{*}$ & $3.94^{*}$ & $0.11 \mathrm{~ns}$ & $0.33 \mathrm{~ns}$ \\
$0700-0800$ & $0.843^{* * *}$ & $12.36^{* * *}$ & $0.73 \mathrm{~ns}$ & $3.62^{* * *}$ & $0.21 \mathrm{~ns}$ & $0.01 \mathrm{~ns}$ \\
$0800-0900$ & $0.849^{* * *}$ & $11.84^{* * *}$ & $1.02^{*}$ & $2.03^{* *}$ & $0.17 \mathrm{~ns}$ & $0.03 \mathrm{~ns}$ \\
$0900-1000$ & $0.825^{* * *}$ & $12.12^{* * *}$ & $1.14^{*}$ & $0.58 \mathrm{~ns}$ & $0.14 \mathrm{~ns}$ & $0.00 \mathrm{~ns}$ \\
\hline
\end{tabular}




\begin{tabular}{ccccc}
\hline \multirow{2}{*}{ Period } & \multicolumn{3}{c}{ Standardized partial regression coefficient } \\
\cline { 2 - 5 } & $\begin{array}{c}\text { Air } \\
\text { temperature }\end{array}$ & $\begin{array}{c}\text { Solar } \\
\text { radiation }\end{array}$ & $\begin{array}{c}\text { Vapor-pressure } \\
\text { deficit }\end{array}$ & $\begin{array}{c}\text { Wind } \\
\text { speed }\end{array}$ \\
\hline $0500-0600$ & -0.108 & -0.035 & 0.042 & 1.124 \\
$0600-0700$ & -0.129 & -0.007 & 0.026 & 0.601 \\
$0700-0800$ & -0.102 & -0.003 & 0.029 & 0.045 \\
$0800-0900$ & -0.131 & -0.002 & 0.027 & 0.059 \\
$0900-1000$ & -0.147 & -0.001 & 0.024 & 0.008 \\
\hline
\end{tabular}

ns (not significant). ${ }^{*}, * *$ and ${ }^{* * *}$ (significant at $p<0.05, p<0.01$, and $p<0.001$ ) respectively.

Table 3. Results of multiple-regression analysis using general linear models for the correlations between five hourly-averaged weather factors (air temperature, solar radiation, vapor-pressure deficit, and wind speed) and the flower opening time for the 1-hr periods based on Japan Standard Time and the significance of the rice cultivar.

The contributions of the four weather factors (air temperature, solar radiation, vaporpressure deficit, and wind speed) were estimated for each cultivar (Table 4.). The contributions of solar radiation and air temperature were higher than those of vaporpressure deficit and wind speed. Among cultivars, the variation in solar radiation was larger than that in air temperature. The contribution of solar radiation in 'Fujihikari' was 45.2 min, whereas its contribution in 'Xiaomazhan' was $3.9 \mathrm{~min}$. The contributions of solar radiation in the cultivars classified as the group that showed negative, high correlations (Fig. 4.) were relatively high.

\begin{tabular}{lcccc}
\hline \multicolumn{1}{c}{ Cultivar } & $\begin{array}{c}\text { Solar } \\
\text { radiation }\end{array}$ & $\begin{array}{c}\text { Air } \\
\text { temperature }\end{array}$ & $\begin{array}{c}\text { Vapor-pressure } \\
\text { deficit }\end{array}$ & $\begin{array}{c}\text { Wind } \\
\text { speed }\end{array}$ \\
\hline 'Fujihikari' & 45.2 & 48.6 & 13.7 & 3.6 \\
'Koshihikari' & 28.9 & 39.4 & 15.3 & 4.0 \\
'Xiaomazhan' & 3.9 & 50.1 & 12.6 & 0.8 \\
'Milky Queen' & 28.1 & 26.0 & 15.3 & 3.4 \\
'IR72' & 37.1 & 48.0 & 14.4 & 1.4 \\
'Takanari' & 5.0 & 20.3 & 10.9 & 1.6 \\
'Asahi' & 33.1 & 45.4 & 11.5 & 1.2 \\
\hline
\end{tabular}

Table 4. Estimated contributions (expressed as min) of the four weather factors (air temperature, solar radiation, vapor-pressure deficit, and wind speed) using the results of general linear models (Table 3.).

\subsubsection{Observation of a diurnal pattern in multiple correlation coefficients in each cultivar}

Two distinctive peaks were observed in the diurnal change of multiple correlation coefficients in each cultivar (Fig. 7). One peak was observed immediately after sunset (20002300) and the other was observed immediately after sunrise (0500-0700). In 'Fujihikari', 'IR72', and 'Milky Queen', highest multiple correlation coefficients of 0.816, 0.559, and 0.571, respectively were obtained for the $0600-0700$ period. In 'Xiaomazhan', the highest multiple correlation coefficient (0.720) was obtained for the $0500-0600$ period. In these four cultivars, 
the peak immediately after sunrise was higher than that immediately after sunset. In 'Fujihikari' and 'Koshihikari', highest multiple correlation coefficients of 0.570 and 0.484 , respectively were obtained for the 2100-2200 period. The highest multiple correlation coefficient (0.716) in 'Asahi' was obtained for the 2200-2300 period. In these three cultivars, the peak immediately after sunrise was lower than that immediately after sunset.
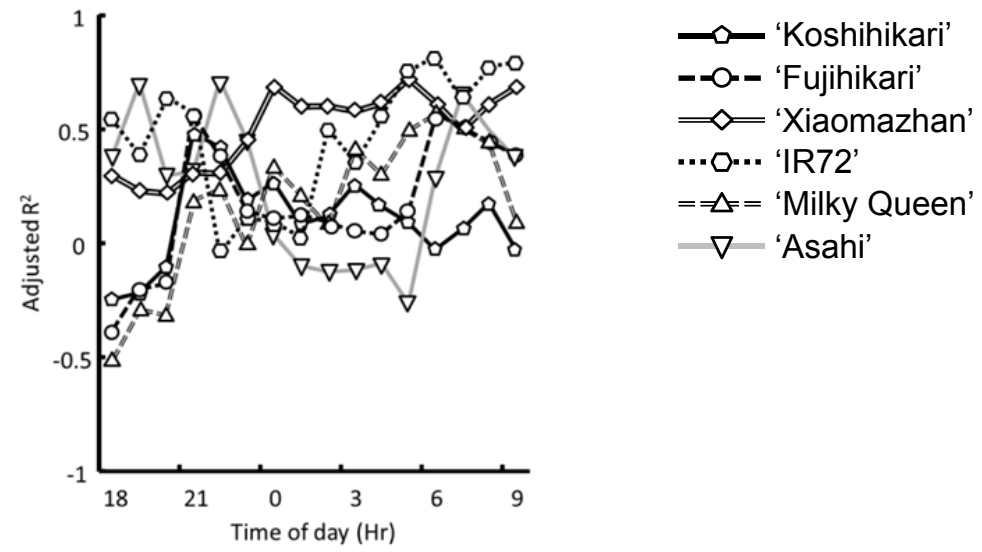

Fig. 7. Multiple correlation coefficients (Adjusted $\mathrm{R}^{2}$ ) for each hour between 1800 on the day before flowering and 0900 on the flowering day for each cultivar.

\subsection{Discussion}

Higher solar radiation after sunrise resulted in an earlier flower opening time because the six cultivars excluding 'Takanari' showed negative correlations between the flower opening time and mean hourly solar radiation for every hour between 0500 and 1000 (Fig. 4). High solar radiation in the morning is related to an early flower opening time in several rice cultivars (Kobayasi et al., 2010). Similarly, solar radiation from 0400 to 0800 influenced the flower opening time in 'Koshihikari', but not in EG0 (Nakagawa \& Nagata, 2007). In this experiment, cultivar differences in the sensitivity of the flower opening time to solar radiation were observed. The cultivars examined in this experiment were classified into two groups: cultivars with negative, high correlations between solar radiation and the flower opening time and those with relatively weak correlations. However, some of our results were inconsistent in that 'Koshihikari' showed a high response to solar radiation in previous studies (Kobayasi et al., 2010; Nakagawa \& Nagata, 2007), but not in this experiment. In 2010, record heat and sunshine occurred, and maximum air temperature was higher than $34^{\circ} \mathrm{C}$ for 23 days, while, in normal years, the maximum air temperature is rarely higher than $34^{\circ} \mathrm{C}$. The mechanism of solar radiation and air temperature in determining the flower opening time is not unclear. Air temperature and solar radiation may synergistically affect the flower opening time by altering panicle tissue temperature.

The correlation coefficients between the flower opening time and hourly solar radiation dropped rapidly at five hours before flower opening for each hour over seven 1-hr periods based on the mean flower opening time in the six cultivars except 'Xiaomazhan' whose flowers opened before 1000 (Fig. 5). The sensitivity of rice flowers to solar radiation during flower opening may increase before flower opening. Pollen grains continue to develop until 
flowering occurs, and they accumulate with starch 1 day before anthesis (Koike \& Satake, 1987). After the end of starch engorgement in the pollen grains, the starch is rapidly digested at the end of the grain opposite to the germ poles 3-4 hr before flower opening; and more than $70 \%$ of pollen grains become sugar-type grains by the time of anther dehiscence (Koike \& Satake, 1987). These findings suggest that development in sugar-type grains and the digestion of starch in the pollen grains are related to the beginning of flower opening. The digestion of starch in the pollen grains starts immediately after sunrise except in 'Xiaomazhan'. These results suggest that an increase in solar radiation triggers flower opening processes. However, the mechanism(s) by which solar radiation triggers starch digestion remains unclear. Pollen grains in anthers receive little solar radiation because they are covered by the palea and lemma of a rice flower. Solar radiation may increase anther temperature and promote starch digestion.

We found the highest multiple correlation coefficient (adjusted $\mathrm{R}^{2}=0.849, p<0.001$ ) for the 0800-0900 period (Table 3). During this period, three factors (cultivar, solar radiation, and air temperature) were significant $(p<0.05)$. The standardized partial regression coefficient for air temperature was -0.131 , indicating that higher air temperature during this period resulted in an earlier flower opening time. Similarly, the standardized partial regression coefficient of solar radiation was -0.002 , indicating that higher solar radiation during this period also resulted in an earlier flower opening time. The standardized partial regression coefficients for the contributions of vapor-pressure deficit and wind speed to the flower opening time were relatively small. These results indicate that it is necessary to consider two weather factors (air temperature and solar radiation) when analyzing the effects of weather on the flower opening time and, the contributions of vapor-pressure deficit and wind speed to the flower opening time were small. We estimated the contributions (hr) to the flower opening time. The contributions of 'Xiaomazhan', 'IR72', 'Takanari', 'Fujihikari', 'Asahi', 'Koshihikari', and 'Milky Queen' were -2.16, -0.89, -0.37, -0.01, 0, 0.41, and 0.437, respectively. Three indica cultivars ('Xiaomazhan', 'IR72', 'Takanari') showed early morning flowering, and the contribution to the flower opening time advancement was the highest in 'Xiaomazhan'. This result agreed with the previous results that 'Xiaomazhan' showed the earliest flower opening time in Japan (Kobayasi et al., 2010) and Jiangsu Province, China (Zhao et al., 2010). On the other hand, 'Milky Queen' did not show early morning flowering in this experiment. This result suggests that weather factors are also important in determining the flower opening time, and the consideration of all weather effects is required in breeding rice cultivars with early morning flowering.

Two distinctive peaks were observed in the diurnal change of multiple correlation coefficients in each cultivar (Fig. 7). One peak was immediately after sunset (2000-2300), and the other was immediately after sunrise (0500-0700). This suggests that other aspects of light conditions such as light cycle may influence the flower opening time in addition to the amount of solar radiation. The flowers of rice plants grown in a chamber tend to open 1-2 hr later than those grown outdoors (Imaki et al., 1982). Artificial dark or light treatments have been reported to affect the flower opening time (Nishiyama \& Blanco, 1981). The effects of the diurnal cycle of light and temperature on the flower opening time in $P$. nil flowers have been studied experimentally (Kaihara \& Takimoto, 1979, 1980, 1981a, 1981b, 1983). P. nil flowers subjected to various photoperiods bloomed approximately $10 \mathrm{hr}$ after light-off when the light period was $10 \mathrm{hr}$ or longer and approximately $20 \mathrm{hr}$ after light-on when the light period was shorter (Kaihara \& Takimoto, 1979). The higher air temperature during the dark 
period resulted in a later flower opening time with the temperature during the last half of the dark period having a stronger effect than that during the first half (Kaihara \& Takimoto, 1980). At the lower temperature, the flower opening time is probably determined by the time of the latest preceding light-off (or light-on) signal (Kaihara \& Takimoto, 1981a). Rice plants grown in a glasshouse or growth chamber have been reported to open flowers 1-2 hr later than those grown outdoors (Imaki et al., 1982).

In P. nil flowers, Kaihara \& Takimoto (1981b) found that petals of the buds are the sites of photo- and thermo-perception; flower opening is caused mainly by the epinasty of petal midribs. On the other hand, we do not know the sites of photo- and thermo-perception in rice. Rice flowers lack petals and sepals. Rice lodicules, which are considered to be organs homologous to petals, expand when a rice flower opens. However, lodicules are covered with a palea and lemma and receive a low level solar radiation. Furthermore, plant growth regulators affect the flower opening time. Among plant growth regulators, abscisic acid promotes the flower opening time in P. nil (Kaihara \& Takimoto, 1983). In rice, methyl jasmonate affects the flower opening time (Kobayasi \& Atsuta, 2010; Zeng et al., 1999). Methyl jasmonate is important for tapetum, stamen, and pollen development in rice (Hirano et al., 2008). Some of plant growth regulators in anthers or lodicules may be triggers for flower opening by increasing solar radiation and air temperature. Advanced study of the sites of photo- and thermo-perception and of the mechanism for flower opening time determination, with consideration of plant growth regulators is needed. Under field conditions, where light intensity varies, it may be difficult to separate the effects of light intensity and the cycle of light and dark. Future research is necessary to study the effect of the light cycle on the flower opening time using growth chambers or supplementary light under field conditions to separate this factor from the effects of light intensity.

\section{Experiment 2: Effects of solar radiation on rice panicle temperature}

Global warming could increase the probability of heat-induced sterility in rice, which is most sensitive during anthesis (Matsui et al., 1997a). In addition, an elevated $\mathrm{CO}_{2}$ concentration raises canopy temperature through stomatal closure, thereby exacerbating heat-stress-induced sterility in rice (Matsui et al., 1997b). The mechanism of heat-stressinduced sterility is explained by the inhibition of anther dehiscence when flowering under high temperature (Satake \& Yoshida, 1978). Atmospheric temperature is usually employed to estimate temperature-dependent stress, but panicle temperature is obviously the major determinant of heat-induced sterility (Zhao et al. 2010). The results in section 2 suggest that panicle temperature also affects the flower opening time, which is strongly related with heat-stress-induced sterility in rice. Together with other microclimates and cultivar-related factors such as transpirational conductance and panicle shape, solar radiation can affect panicle temperature and exacerbate or mitigate temperature-dependent stresses. However, it is difficult to predict panicle temperature change under field conditions because panicles have shapes and characteristics that differ from those leaves on transpiration (Ishihara et al., 1990), which generally leads to a sizeable difference between panicle temperature and leaf/air temperatures (Nishiyama 1981).

Yoshimoto et al. (2005) developed a heat balance model to simulate panicle temperature and its transpiration. However, the model needs many parameters of microclimates. We 
developed a simple and convenient empirical model to estimate the contribution of solar radiation to panicle temperature using generalized linear models in Experiment 2. The contribution of solar radiation for panicle temperature was estimated using this model.

\subsection{Materials and methods}

The study was conducted at the same location in Experiment 1. We used six rice cultivars in this study. The nursery growing and transplanting methods used were similar to those in Experiment 1. Table 6 shows the seeding dates and dates for measuring panicle temperature. The planting density was 22.2 hills $\mathrm{m}^{-2}$. The area of each plot was $12.8 \mathrm{~m}^{2}$. A basal dressing of $4.0 \mathrm{~g} \mathrm{~m}^{-2}$ of $\mathrm{N}, 4.9 \mathrm{~g} \mathrm{~m}^{-2}$ of $\mathrm{P}_{2} \mathrm{O}_{5}$, and $4.3 \mathrm{~g} \mathrm{~m}^{-2}$ of $\mathrm{K}_{2} \mathrm{O}$ was applied. Top dressing was not used. Culture methods such as irrigation and pesticide used followed the standard local practices for rice production in Shimane Prefecture.

\begin{tabular}{ccc}
\hline Cultivar & Seeding dates & Measurement dates \\
\hline 'Fujihikari' & April 20 & July 17, 18 \\
'Koshihikari' & May 18, June 20 & August 13, 15, September 6 \\
'Xiaomazhan' & April 20 & July 29 \\
'Milky Queen' & May 18, June 20 & August 13, 15, September 6 \\
'IR72' & May 18 & September 6 \\
'Asahi' & May 18 & September 6 \\
\hline
\end{tabular}

Table 5. Seeding dates and measurement dates for six O. sativa cultivars in Experiment 2.

\subsubsection{Measurements of panicle temperature and weather}

We measured panicle and leaf temperatures every hour between 0600 and 1200 on the flower opening days (Table 5), using infrared thermography (Neo Thermo TVS-700, Nippon Avionics co. LTD., Tokyo, Japan) with a fixed emissivity factor of 1 . Weather factors (solar radiation, air temperature, relative humidity, and wind speed) were measured every $5 \mathrm{~min}$ using a wireless weather station (Wireless Vantage Pro, Davis Instruments, Hayward, CA, USA) located at Shimane University. Measurement details and calculating weather factors are the same in Experiment 1.

\subsubsection{Statistical analysis}

As there are inherent relationships among weather factors, relatively high correlations may exist among air temperature, solar radiation, vapor-pressure deficit, and wind speed. Therefore, to evaluate their individual effects as well as the cultivar effects on panicle temperature, we analyzed our data by means of generalized linear models and multiple regression procedures using SPSS (Version 14J for Windows, SPSS Japan Inc., Tokyo, Japan). In this analysis, air temperature, solar radiation, and vapor-pressure deficit values were used in one hour intervals between 6000 and 1200 based on Japan Standard Time. The relative contribution of each weather component to panicle temperature was determined using their standardized partial regression coefficients, and the overall strength of the relationships was quantified using the multiple correlation coefficients. 


\subsection{Results}

The weather in 2011 was variable, in contrast with the record hot weather in 2010 (Fig. 9). Air temperature and solar radiation in mid-July to mid-August were high. In 2011, two strong typhoons affected Japan in late July and late August; as a result, air temperature and solar radiation in late July and late August dropped rapidly.

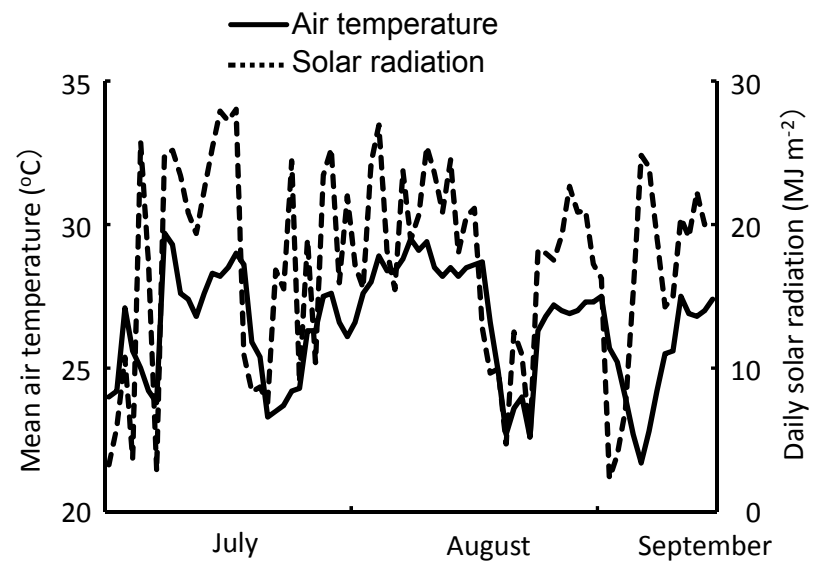

Fig. 8. Daily mean air temperatures and total solar radiation during the observation period.

The weather during the observation hours (0600-1200) differed every on the measuring days (Table 6). On July 17, air temperature was higher than $30^{\circ} \mathrm{C}$, and solar radiation was high $\left(13.5 \mathrm{MJ} \mathrm{m}^{-2}\right)$. On the other hand, solar radiation was low $\left(5.0 \mathrm{MJ} \mathrm{m}^{-2}\right)$ on July 18 . On September 6, air temperature was below $22^{\circ} \mathrm{C}$, but solar radiation was high $\left(12.1 \mathrm{MJ} \mathrm{m}^{-2}\right)$.

\begin{tabular}{ccccc}
\hline $\begin{array}{c}\text { Measurement } \\
\text { date }\end{array}$ & $\begin{array}{c}\text { Air temperature } \\
\left({ }^{\circ} \mathrm{C}\right)\end{array}$ & $\begin{array}{c}\text { Solar radiation } \\
\left(\mathrm{MJ} \mathrm{m}^{-2}\right)\end{array}$ & $\begin{array}{c}\text { Vapor-pressure } \\
\text { deficit }(\mathrm{hPa})\end{array}$ & $\begin{array}{c}\text { Wind speed } \\
\left(\mathrm{m} \mathrm{s}^{-1}\right)\end{array}$ \\
\hline July 17 & 30.2 & 13.5 & 9.6 & 2.5 \\
July 18 & 29.2 & 5.0 & 8.8 & 3.3 \\
July 29 & 28.4 & 11.5 & 7.7 & 5.9 \\
August 13 & 29.5 & 12.5 & 9.0 & 2.4 \\
August 15 & 29.2 & 7.9 & 8.3 & 3.8 \\
September 6 & 22.4 & 12.1 & 4.8 & 2.5 \\
\hline
\end{tabular}

Table 6. Mean air temperature, total solar radiation, mean vapor-pressure deficit, and wind speed between 0600 and 1200 on measuring days in Experiment 2.

\subsubsection{Meteorological variables, panicle and leaf temperatures}

The air temperature on August 13 was similar to that on August 15; on the other hand, the solar radiation was approximately 58\% higher than that on August 15 (Table 6). Solar radiation on August 15 increased between 0600 and 0800, but it decreased between 0800 and 0900 (Fig. 9). The level of solar radiation between 0800 and 1200 on August 15 was lower than that on August 13. 

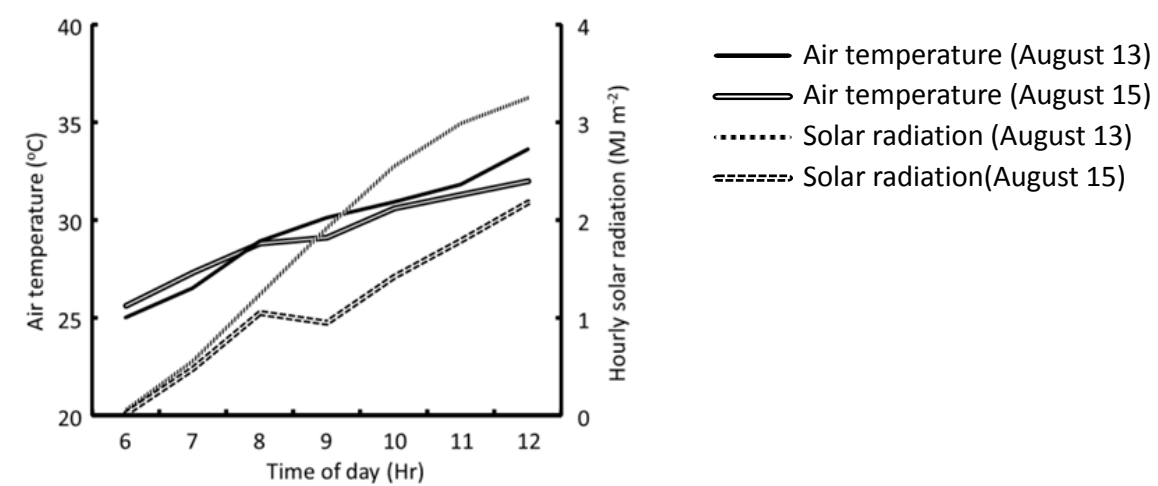

Fig. 9. Solar radiation and air temperature between 0600 and 1200 on August 13 and 15.

Panicle and leaf temperatures in both cultivars were as high as the air temperature between 0600 and 0700. As solar radiation increased, both panicle and leaf temperatures increased above the air temperature, and the differences between the panicle and air temperatures and between the leaf and air temperatures increased. In both cultivars and on both days, the panicle temperature was higher than the leaf temperature by approximately $1^{\circ} \mathrm{C}$. On August 15 , the increases in panicle and leaf temperatures in both cultivars were small between 0800 and 1200, probably because of lower solar radiation. The differences in panicle and leaf temperatures between 'Milky Queen' and 'Koshihikari' were also small.
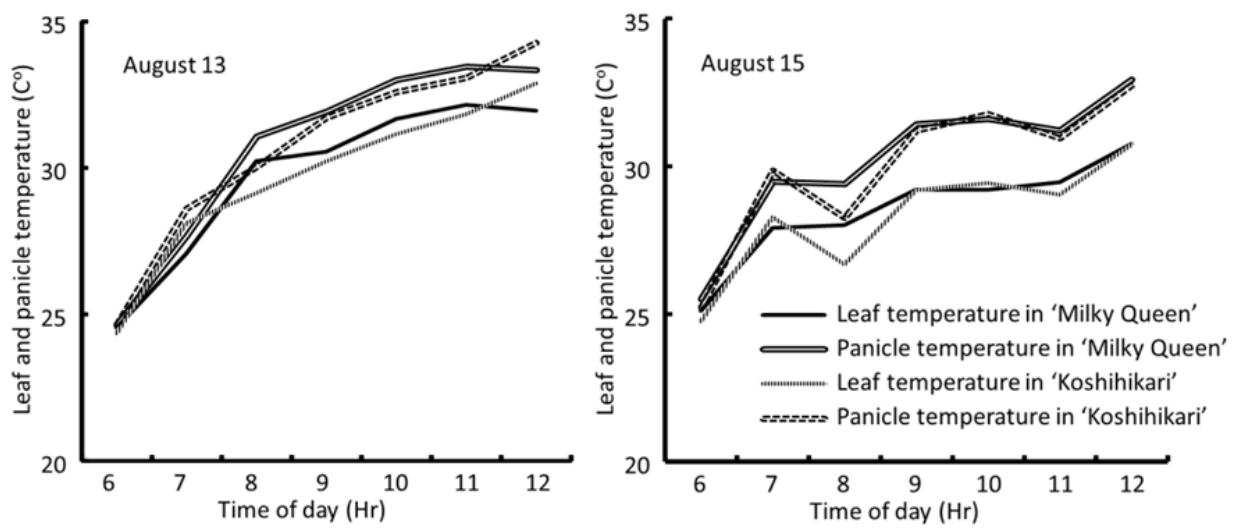

Fig. 10. Leaf temperature and panicle temperature in two rice cultivars ('Milky Queen' and 'Koshihikari') between 0600 and 1200 on August 13 (left figure) and 15 (right figure).

The air temperature on September 6 was lower than that on August 13 and 15; on the other hand, solar radiation on September 6 was as high as that on August 13 (Table 6). Solar radiation on September 6 increased linearly between 0600 and 1200 just as on August 13. However, the air temperature between 0600 and 1200 was less than $30^{\circ} \mathrm{C}$, although air temperature increased linearly at a rate of $1.5^{\circ} \mathrm{C} \mathrm{hr}^{-1}$; this rate was higher than that on August $13\left(1.4^{\circ} \mathrm{C} \mathrm{hr}^{-1}\right)$. 


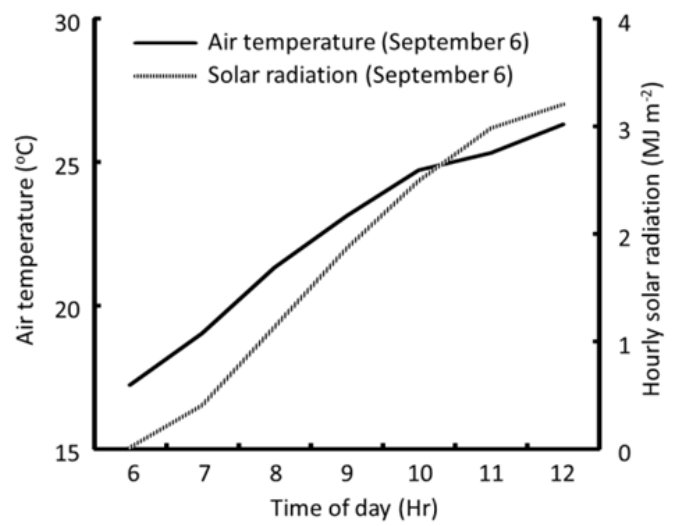

Fig. 11. Solar radiation and air temperature between 0600 and 1200 on September 6 .

Panicle and leaf temperatures in the four cultivars were slightly lower than the air temperature at 0600. As solar radiation increased, panicle and leaf temperatures increased rapidly. In all cultivars, the panicle temperature was higher than leaf temperature by approximately $1-2^{\circ} \mathrm{C}$. However, panicle and leaf temperatures between 0600 and 1200 were less than $30^{\circ} \mathrm{C}$ although they increased at the rate of $1.8^{\circ} \mathrm{C} \mathrm{hr}-1$, which was a higher rate than that on August $13\left(1.4^{\circ} \mathrm{C} \mathrm{hr}-1\right)$. At 1100, panicle and leaf temperatures in 'Asahi' and 'Koshihikari' dropped, but the reason for this decrease was unclear.
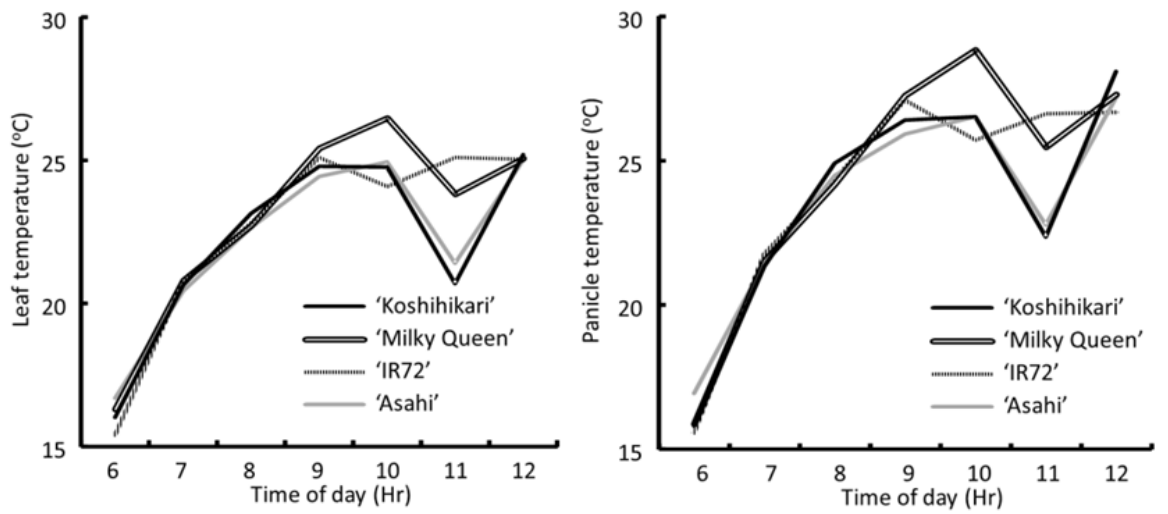

Fig. 12. Leaf (left figure) and panicle (right figure) temperatures in four rice cultivars ('Koshihikari', 'Milky Queen', 'IR72'and 'Asahi') between 0600 and 1200 on September 6.

\subsubsection{Evaluation of the effects of solar radiation, cultivar, air temperature, vapor- pressure deficit, and wind speed on panicle and leaf temperatures}

The multiple correlation coefficient determined by the general linear model for leaf temperature was $0.911(p<0.001)$, and three weather parameters (air temperature, solar radiation, and vapor-pressure deficit) significantly influenced leaf temperature (Table 7). A 
cultivar effect was not observed. The standardized partial regression coefficient for air temperature was 1.580; on the other hand, the standardized partial regression coefficient for solar radiation was small (0.180). The multiple correlation coefficient determined by the general linear model for panicle temperature was $0.891(p<0.001)$, and three weather factors (air temperature, solar radiation, and vapor-pressure deficit) also significantly influenced on panicle temperature (Table 7). A cultivar effect was not detected. The standardized partial regression coefficient for air temperature was 1.430; on the other hand, the standardized partial regression coefficient for solar radiation (0.225) was slightly larger than that of the generalized linear model for leaf temperature.

\begin{tabular}{lccccccc}
\hline & & \multicolumn{3}{c}{$F$ values in the generalized linear models } \\
\cline { 3 - 7 } Dependent variables & $\begin{array}{c}\text { Multiple } \\
\text { correlation } \\
\text { coefficient }\end{array}$ & Cultivar & $\begin{array}{c}\text { Air } \\
\text { temperature }\end{array}$ & $\begin{array}{c}\text { Solar } \\
\text { radiation }\end{array}$ & $\begin{array}{c}\text { Vapor- } \\
\text { pressure } \\
\text { deficit }\end{array}$ & Wind \\
speed \\
\hline Leaf temperature & $0.911^{* * *}$ & $0.42 \mathrm{~ns}$ & $84.91^{* * *}$ & $6.96^{*}$ & $11.30^{* *}$ & $2.92 \mathrm{~ns}$ \\
Panicle temperature & $0.891^{* * *}$ & $1.21 \mathrm{~ns}$ & $85.21^{* * *}$ & $13.32^{*}$ & $10.82^{*}$ & $0.06 \mathrm{~ns}$ \\
\hline
\end{tabular}

\begin{tabular}{ccccc}
\hline & \multicolumn{3}{c}{ Standardized partial regression coefficient } \\
\cline { 2 - 5 } Dependent \\
\cline { 2 - 5 } & $\begin{array}{c}\text { Air } \\
\text { temperature }\end{array}$ & $\begin{array}{c}\text { Solar } \\
\text { radiation }\end{array}$ & $\begin{array}{c}\text { Vapor-pressure } \\
\text { deficit }\end{array}$ & $\begin{array}{c}\text { Wind } \\
\text { speed }\end{array}$ \\
\hline Leaf temperature & 1.580 & 0.180 & -0.702 & -0.072 \\
Panicle temperature & 1.430 & 0.225 & -0.620 & -0.010 \\
\hline
\end{tabular}

ns (not significant). ${ }^{*}, * *$, and ${ }^{* * *}$ (significant at $p<0.05, p<0.01$, and $\left.p<0.001\right)$ respectively.

Table 7. Results of multiple regression analysis using general linear models for the correlations between four weather factors (air temperature, solar radiation, vapor-pressure deficit, and wind speed) and panicle and leaf temperatures for every hour during 0600 and 1200.

\subsection{Discussion}

The direct effects of solar radiation on panicle and leaf temperatures were smaller than those of air temperature and vapor-pressure deficit because the standardized partial regression coefficient for air temperature was much larger than that for solar radiation (Table 7.). Higher solar radiation on August 13 resulted in higher panicle and leaf temperatures (Fig. 10.), but air temperature was also affected by solar radiation; higher air temperature also resulted in higher panicle and leaf temperatures. Yoshimoto et al. (2007) estimated the panicle temperature in New South Wales, Australia and in Jiangsu Province, China, using 
their heat balance model to simulate panicle temperature and its transpiration. In New South Wales, solar radiation was higher and exceeded $1000 \mathrm{~W} \mathrm{~m}^{-2}$ at midday with higher air temperatures of nearly $40^{\circ} \mathrm{C}$; on the other hand, solar radiation is approximately $800 \mathrm{~W} \mathrm{~m}^{-2}$ at midday with modest air temperatures of nearly $35^{\circ} \mathrm{C}$ in Jiangsu Province, China. However, the estimated panicle temperature was lower in New South Wales than in Jiangsu Province due to low relative humidity of $<50 \%$ and high wind speeds $\left(2-6 \mathrm{~m} \mathrm{~s}^{-2}\right)$. Based on these results, we concluded that the effect of solar radiation on panicle temperature is indirect and through increasing air temperature.

Cultivar effects on panicle and leaf temperatures were not observed. However, differences in cultivar may exist in the ability to reduce panicle temperature through panicle transpiration. The change in the reflectance of the surface of the leaves and panicles may mitigate high solar radiation. Purple panicles with low reflectance and white and hairy panicles with high reflectance may respond differently to solar radiation. Research that includes tissue reflectance and conductance for panicle transpiration is needed to estimate panicle temperature accurately. An attempt should be made to conduct another experiment under a wider range of weather factors under field conditions.

\section{Conclusion}

1. Higher solar radiation after sunrise resulted in an earlier flower opening time (Fig. 4). The cultivars examined in this experiment were classified into two groups: cultivars with negative, high correlations between solar radiation and the flower opening time and those with relatively weak correlations.

2. The correlation coefficients between the flower opening time and hourly solar radiation on the mean flower opening time dropped rapidly at $5 \mathrm{hr}$ before flower opening (Fig. 5). This result suggests that the sensitivity of rice flowers to solar radiation in flower opening increases before flower opening.

3. We obtained the highest multiple correlation coefficient (adjusted $\mathrm{R}^{2}=0.849, p<0.001$ ) for the 0800-0900 period (Table 3). During this period, three factors (cultivar, solar radiation, and air temperature) were significant $(p<0.05)$. The standardized partial regression coefficient for air temperature was -0.131 , and that a higher air temperature during this period resulted in an earlier flower opening time. Similarly, the standardized partial regression coefficient of solar radiation was -0.002 , and that higher solar radiation during this period also resulted in an earlier flower opening time.

4. Two distinctive peaks, one immediately after sunset and one immediately after sunrise were observed in the diurnal change of multiple correlation coefficients (Fig. 7). This result suggests that other aspects of solar radiation such as the light cycle may influence flower opening time in addition to the amount of solar radiation.

5. The direct effects of solar radiation on panicle and leaf temperatures were smaller than those of air temperature and vapor-pressure deficit.

\section{Acknowledgments}

We thank Dr. Fumihiko Adachi (Shimane University) for scientific support in obtaining weather data from the Shimane University Web site (http://www.ipc.shimaneu.ac.jp/weather/station/index.html). and Ms. Yuka Omura for technical support in obtaining the data regarding flower opening time. 


\section{References}

Buck, A.L. (1981). New equations for computing vapor pressure and enhancement factor, Journal of Applied Meteorology, Vol. 20, No. 12, (Debember 1981), pp. 1527-1532, ISSN 0894-8763

Hirano, K.; Aya, K.; Hobo, T.; Sakakibara, H.; Kojima, M.; Shim, R.A.; Hasegawa, Y.; Ueguchi-Tanaka, M. \& Matsuoka, M. (2008). Comprehensive transcriptome analysis of phytohormone biosynthesis and signaling genes in microspore/pollen and tapetum of rice, Plant $\mathcal{E}$ Cell Physiology, Vol. 49, No. 10, (October 2008), pp. 1429-1450, ISSN 0032-0781

Horie, T.; Matsui, T.; Nakagawa, H. \& Omasa, K. (1996). Effects of elevated $\mathrm{CO}_{2}$ and global climate change on rice yield in Japan, In : Climate Change and Plants in East Asia, K. Omasa ; K. Kai ; H. Taoda ; Z. Uchijima and M. Yoshino (Eds.), pp. 39-56, SpringerVerlag, ISBN 4-431-70176-1, Tokyo, Japan

Hoshikawa, K. (1989). The Growing Rice Plant-An Anatomical Monograph, Nosan Gyoson Bunka Kyokai, ISBN 978-4-540-88113-8, Tokyo, Japan

Imaki, T.; Jyokei, K. \& Hara, K. (1982). Flower opening under the controlled environments in rice plants, Bulletin of the Faculty of Agriculture, Shimane University, Vol. 16, (December, 1982), pp 1-7, ISSN 0370-940X*

Imaki, T.; Jyokei, K. \& Yamada, I. (1983). Sterility caused by high temperature at flowering in rice plants, Bulletin of the Faculty of Agriculture, Shimane University, Vol. 17, (December, 1983), pp 1-7, ISSN 0370-940X *

Imaki, T.; Tokunaga, S. \& Obara, N. (1987). High temperature sterility of rice spikelets at flowering in relation to flowering time, Japanese Journal of Crop Science, Vol. 56, Extra issue 2, (October 1987), pp. 209-210, ISSN 0011-1848**

Ishihara, K.; Kiyota, E. \& Imaizumi, N. (1990). Transpiration and Photosynthesis characteristics of the panicle in comparison with the flag leaf in the rice plant, Japanese Journal of Crop Science, Vol. 59, No. 2, (September 1990), pp. 321-326, ISSN $0011-1848^{* * *}$

Ishimaru, T.; Hirabayashi, H.; Ida, M.; Takai, T.; San-Oh, Y.A.; Yoshinaga, S.; Ando, I.; Ogawa, T. \& Kondo, M. (2010). A genetic resource for early-morning flowering trait of wild rice Oryza officinalis to mitigate high temperature-induced spikelet sterility at anthesis, Annals of Botany, Vol. 106, No. 3, (September 2010), pp. 515-520, ISSN 0305-7364

Jagadish, S.V.K.; Craufurd, P.Q. \& Wheeler, T.R. (2007). High temperature stress and spikelet fertility in rice (Oryza sativa L.), Journal of Experimental Botany, Vol. 58, No. 7, (May 2007), pp. 1627-1635, ISSN 0022-0957

Jagadish, S.V.K.; Craufurd, P.Q. \& Wheeler, T.R. (2008). Phenotyping parents of mapping populations of rice for heat tolerance during anthesis, Crop Science, Vol. 48, No.3, (May 2008), pp. 1140-1146, ISSN 0011-183X

Kaihara, S. \& Takimoto, A. (1979). Environmental factors controlling the time of floweropening in Pharbitis nil, Plant $\mathcal{E}$ Cell Physiology, Vol. 20, No. 8, (December 1979), pp. 1659-1666, ISSN 0032-0781

Kaihara, S. \& Takimoto, A. (1980). Studies on the light controlling the time of floweropening in Pharbitis nil, Plant \& Cell Physiology, Vol. 21, No. 1, (February 1980), pp. 21-26, ISSN 0032-0781 
Kaihara, S. \& Takimoto A. (1981a). Effects of light and temperature on flower-opening of Pharbitis nil, Plant \& Cell Physiology, Vol. 22, No. 2, (April 1981), pp. 215-221, ISSN 0032-0781

Kaihara, S. \& Takimoto A. (1981b). Physical basis of flower-opening in Pharbitis nil, Plant $\mathcal{E}$ Cell Physiology, Vol. 22, No. 2, (April 1981), pp. 307-310, ISSN 0032-0781

Kaihara, S. \& Takimoto A. (1983). Effects of plant growth regulators on flower-opening of Pharbitis nil, Plant $\mathcal{E}$ Cell Physiology, Vol. 24, No. 3, (April 1983), pp. 309-316, ISSN 0032-0781

Kim, H.Y.; Horie, T.; Nakagawa, H. \& Wada, K. (1996). Effect of elevated $\mathrm{CO}_{2}$ concentration and high temperature on growth and yield of rice. II. The effect on yield and its components of Akihikari rice, Japanese Journal of Crop Science, Vol. 65, No. 4, (December 1996), pp. 644-651, ISSN 0011-1848***

Kobayasi, K.; Matsui, T.; Yoshimoto, M. and Hasegawa, T. (2010). Effects of temperature, solar radiation, and vapor-pressure deficit on flower opening time in rice, Plant Production Science, Vol. 13, No. 1, (January 2010), pp. 21-28, ISSN 1343-943X

Kobayasi, K. \& Atsuta, Y. (2010). Sterility and poor pollination due to early flower opening induced by methyl jasmonate, Plant Production Science, Vol. 13, No. 1, (January 2010), pp. 29-36, ISSN 1343-943X

Koike, S. \& Satake, T. (1987). Sterility caused by cooling treatment at the flowering stage in rice plants. II. The abnormal digestion of starch in pollen grain and metabolic changes in anthers following cooling treatment, Japanese Journal of Crop Science, Vol. 56, No. 4, (December 1987), pp. 666-672, ISSN 0011-1848

Matsui, T.; Omasa, K. and Horie, T. (1997a). High temperature-induced spikelet sterility of japonica rice at flowering in relation to air temperature, humidity and wind velocity conditions, Japanese Journal of Crop Science, Vol. 66, No. 3, (September 1997), pp. 449-455, ISSN 0011-1848

Matsui, T.; Namuco, O.S.; Ziska, L. H. and Horie, T. (1997b). Effects of high temperature and $\mathrm{CO}_{2}$ concentration on spikelet sterility in indica rice, Field Crops Research, Vol. 51, No. 3, (April 1997), pp. 213-219. ISSN 0378-4290

Matsui, T.; Kobayasi, K.; Yoshimoto, M. \& Hasegawa, T. (2007). Stability of rice pollination in the field under hot and dry conditions in the Riverina Region of New South Wales, Australia, Plant Production Science, Vol. 10, No. 1, (January 2007), pp. 57-63, ISSN 1343-943X

Nakagawa, H. \& Nagata, A. (2007). Internal and environmental factors affecting the time of flower-opening in rice, Japanese Journal of Crop Science, Vol. 76, Extra issue 2, (September 2007), pp. 280-281, ISSN 0011-1848**

Nishiyama, I. \& Blanco, L. (1980). Avoidance of high temperature sterility by flower opening in the early morning, Japan Agricultural Research Quarterly, Vol. 14, No. 2, (April 1980), pp. 116-117, ISSN 0021-3551

Nishiyama, I. (1981). Temperature inside the flower of rice plants, Japanese Journal of Crop Science, Vol. 50, No. 1, (March 1981), pp. 54-58, ISSN 0011-1848

Nishiyama, I. \& Blanco, L. (1981). Artificial control of flower opening time during the day in rice plants. I. Preliminary experiments, Japanese Journal of Crop Science, Vol. 50, No. 1, (March 1981), pp. 59-66, ISSN 0011-1848

Nishiyama, I. \& Satake, T. (1981). High temperature damages in rice plants, Japanese Journal of Tropical Agriculture, Vol. 25, No.1, (March 1981), pp. 14-19, ISSN 0021-5260** 
Satake, T. \& Yoshida, S. (1978). High temperature-induced sterility in indica rices at flowering, Japanese Journal of Crop Science, Vol. 47, No. 1, (March 1978), pp. 6-17, ISSN 0011-1848

Tsuboi, Y. (1961). Ecological studies on rice plants with regard to damages caused by wind, Bulletin of the National Institute of Agricutural Sciences, Series A, No. 8, (March, 1961). pp. 1-156, ISSN 0077-4820*

Wang, C.; Yang, J.; Wa, J. and Cai, Q. (2004). Influence of high and low temperature stress on fertility and yield of rice (Oryza sativa L.): Case study with the Yangtze River rice cropping region in China, Abstract of World Rice Research Conference 2004, Tsukuba, Japan, (November 2004), pp 97

Yoshimoto, M.; Oue, H.; Takahashi, H. \& Kobayashi, K. (2005). The effects of FACE (FreeAir $\mathrm{CO}_{2}$ Enrichment) on temperatures and transpiration of rice panicles at flowering stage, Journal of Agricultural Meteorology, Vol. 60, No. 5, (December 2005), pp. 597-600, ISSN 0021-8588

Yoshimoto, M.; Matsui, T.; Kobayasi, K.; Nakagawa, H.; Fukuoka, M. \& Hasegawa, T. (2007). Micrometeorological effects on heat induced spikelet sterility of rice estimated by energy balance model, Japanese Journal of Crop Science, Vol. 76, Extra issue 2, (September 2007), pp. 162-163, ISSN 0011-1848**

Zeng, X.C.; Zhou, X.; Zhang, W.; Murofushi, N.; Kitahara, T. \& Kamuro, Y. (1999). Opening of rice floret in rapid response to methyl jasmonate, Journal of Plant Growth Regulation, Vol. 18, No. 4, (December 1999), pp. 153-158, ISSN 0721-7595

Zhao, L.; Kobayasi, K.; Hasegawa, T.; Wang, C.L.; Yoshimoto, M.; Wan, J. \& Matsui, T. (2010). Traits responsible for variation in pollination and seed set among six cultivars grown in a miniature paddy field with free air at a hot, humid spot in China, Agriculture, Ecosystem and Environment, Vol. 139, No.1-2, (October 2010), pp. 110-115, ISSN 0167-8809

* In Japanese with English summary.

** In Japanese.

*** In Japanese with English abstract. 


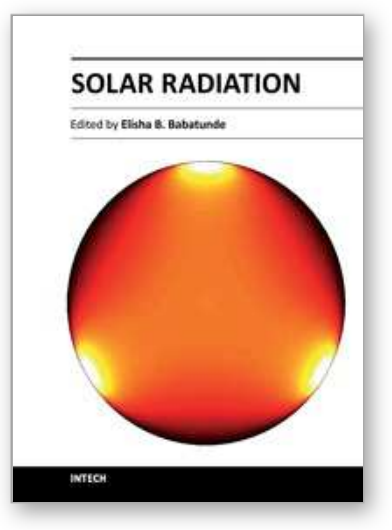

\author{
Solar Radiation \\ Edited by Prof. Elisha B. Babatunde
}

ISBN 978-953-51-0384-4

Hard cover, 484 pages

Publisher InTech

Published online 21, March, 2012

Published in print edition March, 2012

The book contains fundamentals of solar radiation, its ecological impacts, applications, especially in agriculture, architecture, thermal and electric energy. Chapters are written by numerous experienced scientists in the field from various parts of the world. Apart from chapter one which is the introductory chapter of the book, that gives a general topic insight of the book, there are 24 more chapters that cover various fields of solar radiation. These fields include: Measurements and Analysis of Solar Radiation, Agricultural Application / Bio-effect, Architectural Application, Electricity Generation Application and Thermal Energy Application. This book aims to provide a clear scientific insight on Solar Radiation to scientist and students.

\title{
How to reference
}

In order to correctly reference this scholarly work, feel free to copy and paste the following:

Kazuhiro Kobayasi (2012). Effects of Solar Radiation on Fertility and the Flower Opening Time in Rice Under Heat Stress Conditions, Solar Radiation, Prof. Elisha B. Babatunde (Ed.), ISBN: 978-953-51-0384-4, InTech, Available from: http://www.intechopen.com/books/solar-radiation/effects-of-solar-radiation-on-fertility-and-theflower-opening-time-in-rice-under-heat-stress-condit

\section{INTECH}

open science | open minds

\section{InTech Europe}

University Campus STeP Ri Slavka Krautzeka 83/A 51000 Rijeka, Croatia Phone: +385 (51) 770447

Fax: +385 (51) 686166 www.intechopen.com

\section{InTech China}

Unit 405, Office Block, Hotel Equatorial Shanghai No.65, Yan An Road (West), Shanghai, 200040, China 中国上海市延安西路65号上海国际贵都大饭店办公楼 405 单元 Phone: +86-21-62489820

Fax: $+86-21-62489821$ 
(C) 2012 The Author(s). Licensee IntechOpen. This is an open access article distributed under the terms of the Creative Commons Attribution 3.0 License, which permits unrestricted use, distribution, and reproduction in any medium, provided the original work is properly cited. 